\title{
POTABLE WATER FROM INDUSTRIAL WASTEWATER
}

\author{
M. S. Ali*, M. R. Khan and T. Afroz \\ Department of Chemical Engineering, Bangladesh University of Engineering \& Technology, Dhaka-1000, Bangladesh
}

Received 30 May 2008; received in revised form 18 June 2008

\begin{abstract}
The objective of the study was to treat the textile wastewater and convert it into potable grade water in the laboratory scale. It involved a rigorous treatment procedure involving screening, coagulation, flocculation, aeration, biological treatment, filtration and ion exchange. From the analysis of the treated water it can be said that the industrial waste water can be converted into potable grade water.
\end{abstract}

Keywords: Wastewater treatment, Zero discharge, Potable water.

\section{INTRODUCTION}

Textile is one of the major polluting industries in Bangladesh and the effluent from the dyeing and finishing section is a major source of water pollution. Its effect is becoming more evident with the increase in the number of textiles in the country. The wastewaters which are characterized by high alkalinity, high BOD and high suspended solids are often disposed off to nearby rivers, ponds or lakes without proper treatment. They contaminate and decrease the amount of fresh water in addition to causing serious damage to ecology and aquatic lives. Therefore, under the circumstances it will be helpful to think of ways to treat the textile wastewater so that it can be reused.[1]

wastewater from a synthetic fabric dyeing and finishing plant in the laboratory and to establish a treatment procedure to convert the wastewater into potable grade water in the laboratory.

Depending on the characteristics of wastewater and its waste content or pollutant content, treatment techniques may vary. Treatment of wastewater from a textile industry will be different from treatment of waste water from a fertilizer plant or from a Tannery [2-4]. The upstream (discharged from industry) water quality mainly determines how the treatment should be carried out and also the most important factor for treatment is the chemical doses. Another important consideration is whether the treated effluent will be discharged or it will be reused or it will be recycled back to mix-up with the main stream to meet the zero discharge regulation. The most important factor that should be stated here is that depending on the production facilities and raw material used for an industry for any particular period (unless it is continuous and regular process plant) wastewater quality may vary from time to time. So in choosing the treatment techniques, water with the maximum waste content should be taken as the basis. In general waste water treatment stages can be classified as [2-5]:

a) Preliminary Treatment b) Primary Treatment C) Secondary Treatment d) Natural / Biological Treatment e) Tertiary or Advanced Treatment f) Disinfection and g) Effluent Storage.

For this purpose wastewater samples were collected from the finishing and dyeing section of a renowned textile industry situated in Savar, Dhaka. The wastewater was first analyzed in the laboratory to get an idea about its metal content, acidity, solid content and other biological aspects. It was then treated in the laboratory using some standard treatment procedures.

\section{EXPERIMENTAL PROCEDURE}

The experimental work thus can be divided into three parts- analysis of the raw water, treatment of the raw water and finally the analysis of the treated water (Potable grade water)

For the qualitative analysis of raw wastewater, the following parameters were measured in the laboratory :- $\mathrm{pH}$, Total Dissolved Solid (TDS ), Total Suspended Solid ( TSS ), Total Solid ( TS ), Turbidity, Color, Dissolved Oxygen, Specific Conductance, Biochemical Oxygen Demand (BOD) , Chemical Oxygen Demand (COD ) and Different metal ion concentration. All of these parameters were measured using available standard methods.

The treatment involved a rigorous treatment procedure involving screening, coagulation, flocculation, aeration, biological treatment, filtration and ion exchange. Process steps in the laboratory scale treatment of wastewater are shown in Figure 1.

The wastewater sample was collected from the Dying and Finishing section of the textile industry. Screening of the sample was carried out with a piece of cotton cloth and its $\mathrm{pH}$ and TDS were measured. Its $\mathrm{pH}$ was then controlled with the 


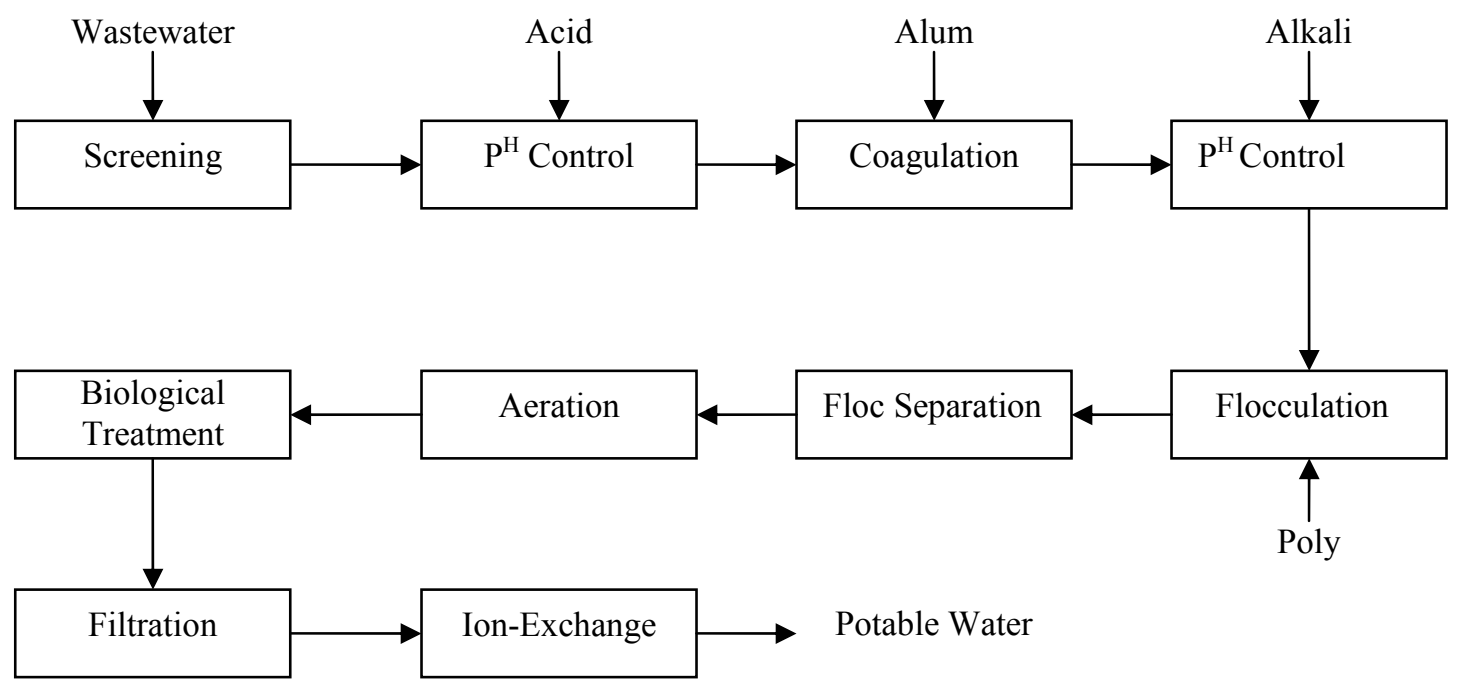

Figure 3: Schematic diagram of the Laboratory scale treatment plant.

addition of commercial grade $\mathrm{H}_{2} \mathrm{SO}_{4}$ and simultaneous aeration was carried out.

Alum (aluminum sulphate) was added to this $\mathrm{pH}$ controlled solution as a coagulating agent. It was stirred for proper mixing. During the process successful separation of solid was observed. Addition of alum decreased the $\mathrm{pH}$. So $\mathrm{NaOH}$ solution was added to increase the $\mathrm{pH}$. It was homogenized with a magnetic stirrer and kept for a few minutes. Polyelectrolyte solution was then added as a flocculating agent. It was stirred with a magnetic stirrer for proper mixing.

After floc formation an appreciable amount of floc was removed and the sample was then fit for biological treatment. Before the biological treatment aeration was carried out for a total of 24 hrs in intervals. Urea, food grade phosphoric acid and a commercial nutrient was added to the aerated sample. It was stirred for proper mixing and aeration was again carried for a total of $24 \mathrm{hrs}$ in intervals.

This biologically treated water sample was then passed through a filter bed consisting of different size sands and stones.

After sand filtration the effluent was passed through an ion exchange resin bed that consisted of a mixture of cationic and anionic resins in the 2:1 ratio. The treated water was then finally taken for analysis.

The parameters measured for the analysis of treated water were same as those for the analysis of waste water.

\section{RESULTS AND DISCUSSION}

Different qualitative parameters of water samples (waste, treated \& potable) that includes the physical parameters (TDS, $\mathrm{pH}$, Color, Turbidity, Specific conductance) and Chemical parameters
(BOD, COD, DO, Metal ion concentration.) were measured using the available standard methods in the laboratory. The experimental results are presented in Table 1 and in Figures 2 to 5 . Comparison of the Laboratory treated water with the International Standard Potable water (World Health Organization Standard, WHO) as well as with the raw waste water are also included to get a good effective representation of the study.

By comparing the values of the different parameters of the laboratory treated water with the standard ones given by WHO or UPSH it is found that all the values lay within the permissible limit. The total dissolved solid(TDS) of the sample was decreased from $1100 \mathrm{mg} / \mathrm{L}$ to $208 \mathrm{mg} / \mathrm{L}$ and it lies within the highest permissible limit of $500 \mathrm{mg} / \mathrm{L}$. The biochemical oxygen demand (BOD)( which gives an idea about the organic waste content) of the sample was very high $(1100 \mathrm{mg} / \mathrm{L})$. The rigorous stepwise treatment decreased the BOD to $2.4 \mathrm{mg} / \mathrm{L}$ which lies within the highest permissible limit of $6 \mathrm{mg} / \mathrm{L}$. The chemical oxygen demand (COD) and dissolved oxygen (DO) are the other two important water quality parameters which should be compared. COD of the sample has been decreased from $282 \mathrm{mg} / \mathrm{L}$ to $2 \mathrm{mg} / \mathrm{L}$ while $\mathrm{DO}$ of the sample has increased to $7.19 \mathrm{~g} / \mathrm{L}$. The concentrations of the toxic metal like arsenic, cadmium, lead ,barium, chromium, cyanide were decreased significantly during the laboratory treatment and the values of their final concentration were found to be within the permissible limit. However the organic toxicity of the wastewater sample and the treated water were not measured, so it cannot be concluded that the treated water would be safe for drinking. 
Table 10: Characteristics of wastewater, laboratory treated potable grade water and standard potable water

\begin{tabular}{llll}
\hline Parameters & Waste water & $\begin{array}{c}\text { Laboratory } \\
\text { potable grade water }\end{array}$ & $\begin{array}{c}\text { treated } \\
\text { Potable water quality } \\
\text { standard [,3] }\end{array}$ \\
\hline $\mathrm{pH}$ & 9.5 & 7.02 & $6.5-9.2$ \\
Specific Conductance & $1404 \mu \mathrm{S} / \mathrm{cm}$ & $406 \mu \mathrm{S} / \mathrm{cm}$ & $400 \mu \mathrm{S} / \mathrm{cm}$ \\
Arsenic & $<10$ & Trace & $0.05 \mathrm{mg} / \mathrm{L}$ \\
Ammonia & $169.8 \mathrm{mg} / \mathrm{L}$ & $2.8 \mathrm{mg} / \mathrm{L}$ & $0-5 \mathrm{mg} / \mathrm{L}$ \\
$\mathrm{BOD}$ & $449 \mathrm{mg} / \mathrm{L}$ & $2.4 \mathrm{mg} / \mathrm{L}$ & $6 \mathrm{mg} / \mathrm{L}$ \\
COD & $282 \mathrm{mg} / \mathrm{L}$ & $2 \mathrm{mg} / \mathrm{L}$ & $10 \mathrm{mg} / \mathrm{L}$ \\
Copper & $3 \mathrm{mg} / \mathrm{L}$ & $0.113 \mathrm{mg} / \mathrm{L}$ & $1.5 \mathrm{mg} / \mathrm{L}$ \\
Nickel & $0.30 \mathrm{mg} / \mathrm{L}$ & $0.001 \mathrm{mg} / \mathrm{L}$ & $0.02 \mathrm{mg} / \mathrm{L}$ \\
Cadmium & $1.6 \mathrm{mg} / \mathrm{L}$ & $3.9 \mu \mathrm{L} / \mathrm{L}$ & $0.01 \mathrm{mg} / \mathrm{L}$ \\
Lead & $17.6 \mathrm{mg} / \mathrm{L}$ & $9 \mu \mathrm{g} / \mathrm{L}$ & $0.1 \mathrm{mg} / \mathrm{L}$ \\
Iron & $29.6 \mathrm{mg} / \mathrm{L}$ & $0.085 \mathrm{mg} / \mathrm{L}$ & $1 \mathrm{mg} / \mathrm{L}$ \\
TS & $2016 \mathrm{mg} / \mathrm{L}$ & $226 \mathrm{mg} / \mathrm{L}$ & \\
TDS & $1100 \mathrm{mg} / \mathrm{L}$ & $208 \mathrm{mg} / \mathrm{L}$ & $500 \mathrm{mg} / \mathrm{L}$ \\
TSS & $916 \mathrm{mg} / \mathrm{L}$ & $18 \mathrm{mg} / \mathrm{L}$ & $10 \mathrm{FAU}$ \\
Turbidity & $44 \mathrm{FAU}$ & $5 \mathrm{FAU}$ & $0.05 \mathrm{mg} / \mathrm{L}$ \\
Chromium & $4.4 \mathrm{mg} / \mathrm{L}$ & $0.01 \mathrm{mg} / \mathrm{L}$ & $0.05 \mathrm{mg} / \mathrm{L}$ \\
Cyanide & $0.6 \mathrm{mg} / \mathrm{L}$ & $0.009 \mathrm{mg} / \mathrm{L}$ & $150-600 \mathrm{mg} / \mathrm{L}$ \\
Chloride & $38 \mathrm{mg} / \mathrm{L}$ & $310 \mathrm{mg} / \mathrm{L}$ & $45 \mathrm{mg} / \mathrm{L}$ \\
Nitrate + nitrite & $60 \mathrm{mg} / \mathrm{l}$ & $0.8 \mathrm{mg} / \mathrm{l}$ & \\
Color & $8.14 \mathrm{mg} / \mathrm{L}$ & Trace & $15 \mathrm{Pt}-\mathrm{Co}$ \\
DO & $520 \mathrm{Pt}-\mathrm{Co}$ & $10 \mathrm{Pt}-\mathrm{Co}$ & $6 \mathrm{mg} / \mathrm{L}$ \\
\hline
\end{tabular}

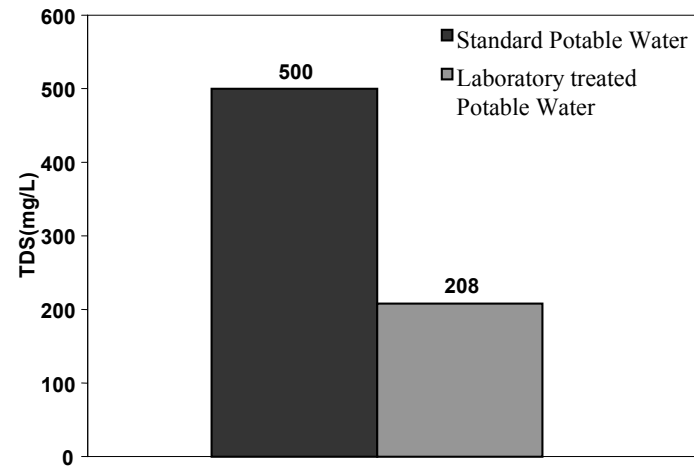

Figure 4: Comparison of the TDS of Standard potable water and Laboratory Treated Potable water

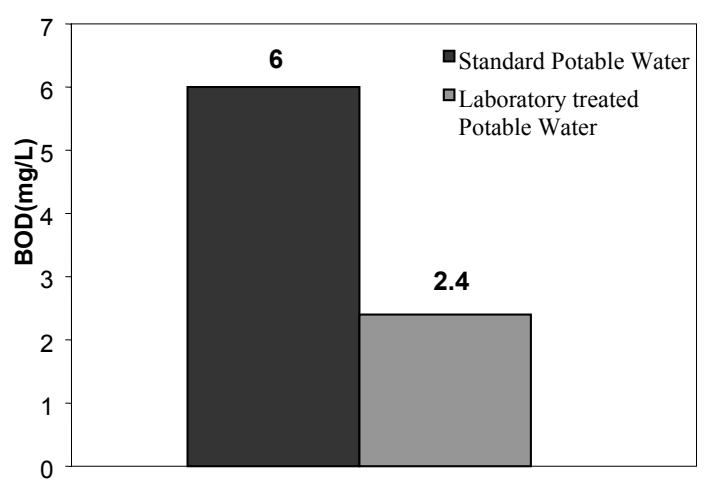

Figure 5: Comparison of the BOD of Standard Potable water and Laboratory Treated Potable water

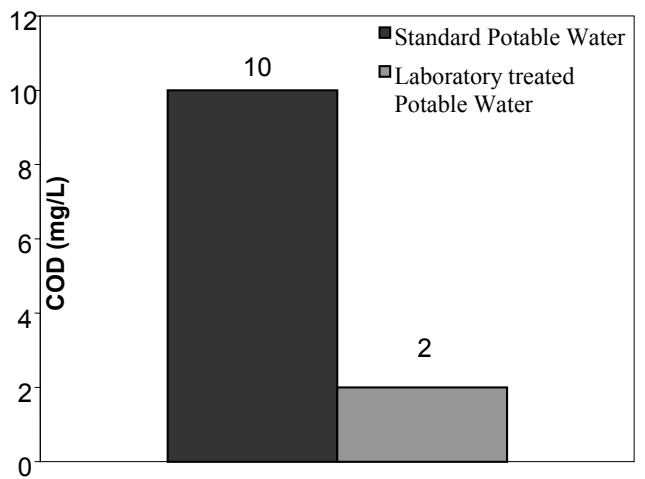

Figure 6: Comparison of the COD of Standard Potable water and Laboratory Treated Potable water

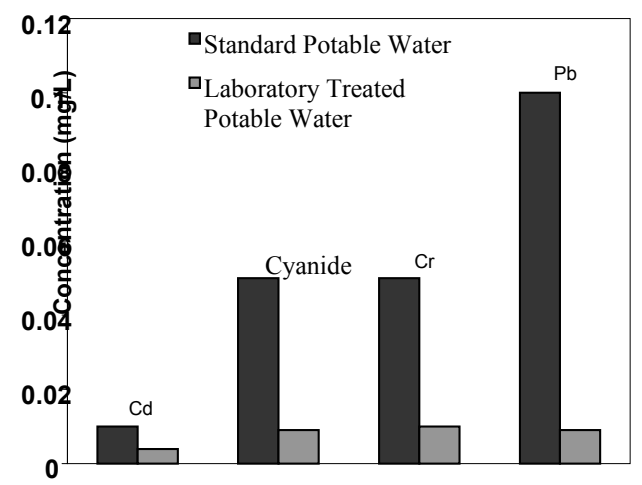

Figure 7: Comparison of Cyanide and Heavy Metal concentration of Standard Potable water and Laboratory Treated Potable water 


\section{CONCLUSION}

This study us a demonstration of effective industrial waste water treatment. If applied commercially, the industrial waste water can be recycled as potable water to complete the reuse cycle and zero discharge effluent from industry.

\section{REFERENCES}

1. Khan, M.R. and T. Afroz, Potable water from industrial wastewater, B.Sc Engineering Thesis, in Department of Chemical Engineering. 2007, Bangladesh University of Engineering \& Technology: Dhaka.
2. Sharma, B.K., Environmental Chemistry. 2003, India: Goel Publishing House.

3. American Water Works Association, Water Treatment Principles. 1984, New York: ASA Publication.

4. American Water Works Association, Water Quality and Treatment. 1971, New York: McGraw-Hill.

5. Nalco water Treatment Handbook. 1988, New York: McGraw-Hill.

6. DE, A. K., Environmental Chemistry. 2000, India: New Age International Publishers. 